\title{
Assessment of the impact of US Energy Policy on world oil prices
}

The development of the energy sector in the United States of America (USA) represents a rivalry between two different approaches, which has intensified under the last three American administrations. The competition of approaches is expressed in the confrontation between supporters of energy based on renewable sources and supporters of traditional energy resources.

A comparative analysis of changes in the energy sector, depending on the prevalence of a particular approach to energy development, shows that external conditions play a key role in promoting the energy strategy. The strategy of priority development of "green" energy carried out under Barack Obama could not be realized because of the shale boom. As a result, many companies working with renewable energy sources did not stand up to the competition. The opposite approach of Donald Trump's focus on developing traditional energy resources to ensure US energy security and to increase jobs has been hit by the COVID-19 pandemic, which has virtually nullified the US administration's efforts under this approach. The current concept of President J. Biden is aimed at continuing the strategy of Barack Obama for the development of "green" energy in the United States. Proponents of this concept hope for the possibility of its at least partial implementation in the absence of a shale boom.

The lifting of the embargo on the export of American oil has led to an increase in oil supplies abroad. As of 2018, the United States has overtaken Saudi Arabia in terms of oil and gas exports, taking a leading position in the global oil market. In 2019-2020, the United States retained the first place in the world in oil production.

This article examines the conceptual approaches of

Blind peer reviews carried out

Ms. Larisa G. Chuvakhina, PhD in Economics, Associate Professor, Department of World Economy, and International Business, Mr. Nikolai A. Moldenhauer and Ms. Anahita Nasirbeik, Postgraduate student, Department of World Economy \& International Business, Faculty of International Economic Relations, Financial University under the Government of the Russian Federation, 49, Leningradsky Avenue, Moscow, 125993, Russia. E-mail: 1-econom@mail.ru / nikolaj.moldenhauer@gmail.com / a.nasirbeik@yandex.ru; Correspondence: a.nasirbeik@yandex.ru
American administrations to the issue of energy policy and analyzes the statistical data that characterize the traditional and "clean energy" industries.

An important factor is the degree of influence of the US energy policy on global oil prices. To analyze this issue, this research uses curved regression equations to assess the impact of US energy policy on world oil prices under the administrations of Barack Obama and Donald Trump. The results of the correlation show that a more effective interaction between the variables was carried out during the presidency of Barack Obama, when Exports of Crude Oil influenced the price dynamics of oil quotes with an inverse relationship.

With the arrival of the Biden administration, the strategy started under Obama in favor of developing clean energy was continued. In the context of the spread of covid-19, the growth of crisis phenomena in the national economy, the growth of production costs in the oil and gas industry, and the fall in the world energy prices, the development of green energy can have a certain effect, given the Biden administration's approach to energy development. The subsequent actions of the Biden administration may offset Trump's efforts to develop traditional energy to strengthen the economic potential of the United States and strengthen the position of American companies in the global oil market.

Keywords: Renewable energy sources, traditional energy, oil and gas industry, $\mathrm{CO}_{2}$ emissions, export/import of energy resources, US Energy Policy.

\subsection{Introduction}

$\mathrm{T}$ The development of US Energy Policy is the outcome of a competition between two opposing approaches to ensuring energy security. One approach is aimed at developing innovative methods for generating energy from renewable sources. Another approach puts the development of the US energy complex with the help of traditional energy sources in the first place. The administration of the current US President, J. Biden, who co-authored the green energy strategy under President Barack Obama, is focused on promoting the first approach. In contrast to this approach, the administration of D. Trump promoted the development of traditional energy sources. This rivalry between the two 
approaches determines the current trends in US Energy Policy.

\subsection{Theoretical ASPECTS OF THE STUdY}

Scientists Yuehong Lu, Zafar A. Khan, Manuel S. AlvarezAlvarado, Yang Zhang, Zhijia Huang and Muhammad Imran (Lu, et al., 2020) in their research note the important role of energy conservation in the efficient functioning of the energy complex and suggest focusing on the problem of building reconstruction with the aim of energy efficiency of energy consumption.

Researchers J. Larsen, S. Mohan, P. Marsters, W. Herndon (Larsen, Mohan, Marsters, \& Herndon., 2018) note that the solution to minimize greenhouse gas emissions can be the introduction of an appropriate tax, which will reduce emissions by $13-29 \%$, summarizing that this measure will have the greatest effectiveness in electricity generation.

Together with the introduction of a tax on greenhouse gas emissions, researcher D. Poneman (Poneman, 2017) believes that attention should be paid to improving nuclear energy production technologies and increasing funding for basic research on a long-term basis. Taken together, these measures can lead to an increased likelihood of breakthrough technologies, which will contribute to economic growth. Scientist D. Koranyi (Koranyi., 2016) agrees with this point of view, who considers nuclear power a temporary solution on the way to the dominance of renewable energy sources, which will eventually lead to the absence of harmful emissions into the atmosphere.

Thus, the researchers see the improvement of the US energy complex in the form of several stages. At the first stage, these are investments in energy-saving technologies with the parallel introduction of a tax on greenhouse gas emissions. The second stage is the improvement of nuclear energy technologies and the search for new solutions in the field of renewable energy sources. The third stage is the transition to a qualitatively different energy sector, where $\mathrm{CO}_{2}$ emissions will be reduced to zero.

\subsection{Research}

The modern energy policy of the United States should start with the presidency of Barack Obama, when a new program of action was adopted, aimed at forming a new energy concept by shifting the balance in energy consumption in favor of renewable energy sources, along with reducing the use of traditional (oil, gas, coal) energy sources. The adopted concept reflected in the document "B. Obama and J. Biden. New Energy for America" (letter, 2008) comes down to the following points:

- social support for low-income families suffering from high fuel prices;

- allocation of $\$ 150$ billion for renewable energy over 10 years to create 5 million jobs;
- increase the use of hybrid vehicles to 1 million by 2015 ;

- ensure $10 \%$ of electricity generation from renewable energy sources by 2012 and up to $25 \%$ by 2025 ;

- reduce greenhouse gas emissions by $80 \%$ by 2050 .

The key aspect contributing to the promotion of the above-mentioned concept was the creation of a full production cycle in the field of "green energy", as a result of which the finished product was exported. This approach helped to stimulate employment growth and consequently, welfare growth against the background of a decrease in external factors of energy dependence, which was reflected in the adopted "National Security Strategy" of 2010 (WhiteHouse, National Security Strategy, 2010).

The possibility of the US transition to a "green economy" was ensured by increasing investment in R\&D, which was supposed to reach at least 3\% of GDP, and by doubling funding for the Department of Energy's Office of Science over 10 years. The main funds in R\&D under Barack Obama accounted for nuclear energy $(27.4 \%)$, technologies in the field of hydrocarbons $(23.5 \%)$, renewable energy sources $(18.5 \%)$, energy conservation (15.8\%) and "smart" energy systems (14.7\%) (ARPA-E, 2014). Being a supporter of the line of Barack Obama in the development of innovation, the current President of the United States, George W. Bush. Biden established the President's Council of Advisors on Science and Technology. It is stated that this council will provide the new administration with information of a scientific and technical nature. The council will also provide direct advice to the President of the United States on science and technology issues that influence the providence of public policy in the economy, social sphere, energy and environmental issues (White-House, 2021).

In general, high levels of R\&D funding are achieved by investing in national laboratories, which account for up to $40 \%$ of the total innovation expenditure of the Ministry of Energy (Schacht, 2009). This is facilitated by organizing the laboratories whose activities are aimed at creating energyintensive batteries, searching for substitutes for scarce resources, and developing energy-saving technologies - in Energy Innovation Hubs, whose activities began in 2012 with an annual budget of $\$ 112$ million.

In addition, activities aimed at finding alternative energy sources are focused on the exploration of rare earth resources, which has led to the creation of specialized centers for breakthrough technologies, the so-called Energy Frontier Research Centers. One of these centers is the Clear Energy Manufacturing Innovation Institute, whose activity is to research processors and other electronic components for alternative energy.

The procedure for issuing licences for the construction of renewable energy facilities has been simplified. Renewable energy projects aimed at energy saving for households, as 
well as projects for the commissioning of "safe" nuclear reactors, have been developed.

D. Trump, who as a representative of the Republican Party, traditionally stands for the development of nuclear energy, continued the line of the previous administration regarding its development. Since 12 obsolete nuclear reactors will be decommissioned in the next 10 years, the US position in the nuclear power industry does not correspond to the national security strategy. At the same time, the growth in the use of nuclear energy is limited by the widespread use of traditional energy sources.

For the development of nuclear energy in February 2018, a new US nuclear doctrine was adopted, according to which the construction of new nuclear reactors should be started, and the research base that restricts the development of nuclear energy in modern conditions should be revised. In February and March 2018, the US Congress held the first discussions on two bills providing for the creation and construction of an "American MBIR" (Multi-purpose fast neutron reactor) by 2025 . The allocation of about $\$ 2$ billion for this purpose was discussed.

Actions of US Presidents B. Obama and D. Trump led to a noticeable reduction in greenhouse gas emissions. Compared to 1999 , total emissions have decreased by $20 \%$ over the past 20 years by the end of 2020 . At the same time, emissions from the use of petroleum products decreased by $16 \%$, and coal by $58 \%$. The transition to a cleaner source of traditional energy sources, i.e., natural gas, has reduced greenhouse gas emissions by up to $38 \%$ by the end of 2020 (EIA U. E., 2021). The above-mentioned indicators are provided in the Fig.1.

Biden intends to go even further, setting a goal to stop greenhouse gas emissions in the US energy sector by 2035 . and completely eliminate $\mathrm{CO}_{2}$ emissions to the atmosphere by 2050 (White-House, FACT SHEET: President Biden Takes Executive Actions to Tackle the Climate Crisis at Home and Abroad, Create Jobs, and Restore Scientific Integrity Across Federal Government, 2021). The first steps in this direction have already been taken through the signing of the executive order by J. Biden on re-joining of the United States to the Paris Climate Agreement of January 27, 2021 (White-House, Executive Order on Tackling the Climate Crisis at Home and Abroad, 2021).
CO2 Emissions dynamics to $1999, \%$

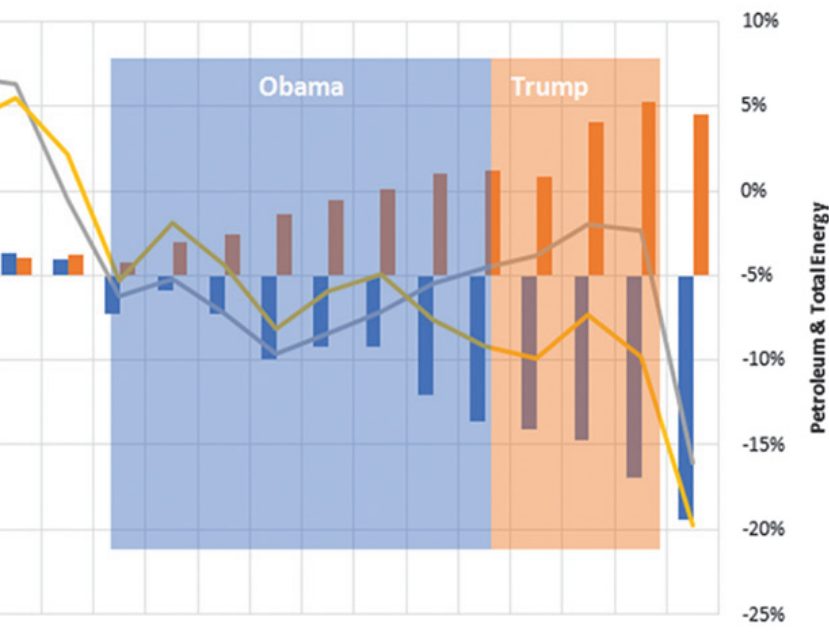

ig.1: $\mathrm{CO}_{2}$ Emissions dynamics to 1999 inpercentage

In general, it can be noted that on the background of the reduction in greenhouse gas emissions initiated under Barack Obama, the share of emissions from the use of coal decreased along with the increase in the use of natural gas. This trend reached its peak under D. Trump and the development of traditional energy sources, which caused the failures of a number of companies working in the field of "green energy". The "shale revolution" that unfolded in the United States was a deterrent to the development of "clean energy" (SINK, 2012).

Only in 2015, the embargo on oil exports from the United States, imposed in response to the oil crisis of the 1970s, was lifted. The lifting of the embargo was made possible as a result of the "shale boom" and the glut of the domestic oil market. The process was initiated by multinational corporations in cooperation with the authorities. The International Affairs Council, the Center for Strategic and International Studies, the Center for a New American Security, the U.S. Energy Information Administration, and the U.S. Chamber of Accounts participated in the discussion on the feasibility of making this decision. In 2015, they presented an analytical report confirming the possible decline in consumer prices for crude oil in the event of the lifting of the embargo and the simultaneous strengthening of the American position in the international energy market (Clayton, 2013).

Simultaneously with the decision to lift the oil export restrictions, the task was set to reduce the import of oil and gas to the United States. This position was explained, firstly, by an increase in domestic oil and gas production; secondly, by a certain decrease in domestic oil consumption caused by an increase in energy efficiency and energy conservation; and thirdly, by an increase in the production of renewable energy sources. The dynamic of US oil and gas production is 


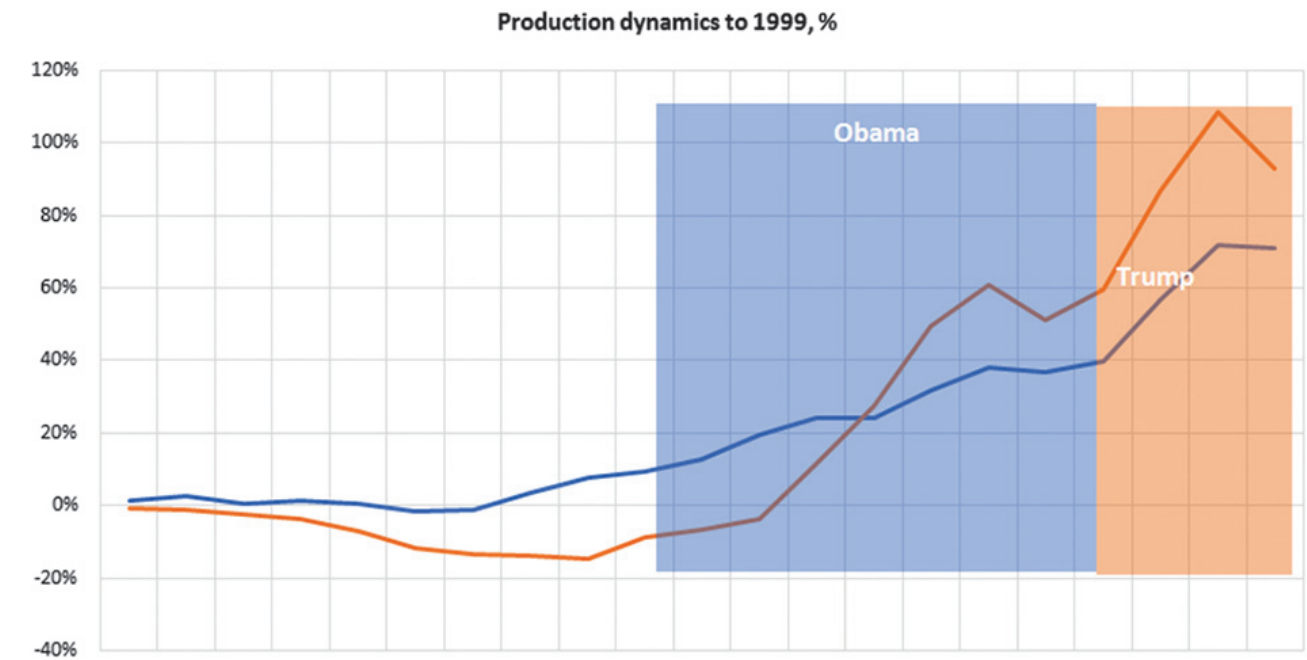

200020012002200320042005200620072008200920102011201220132014201520162017201820192020 - Natural Gas _Crude Oil

Fig.2: The US oil and gas production dynamics to 1999

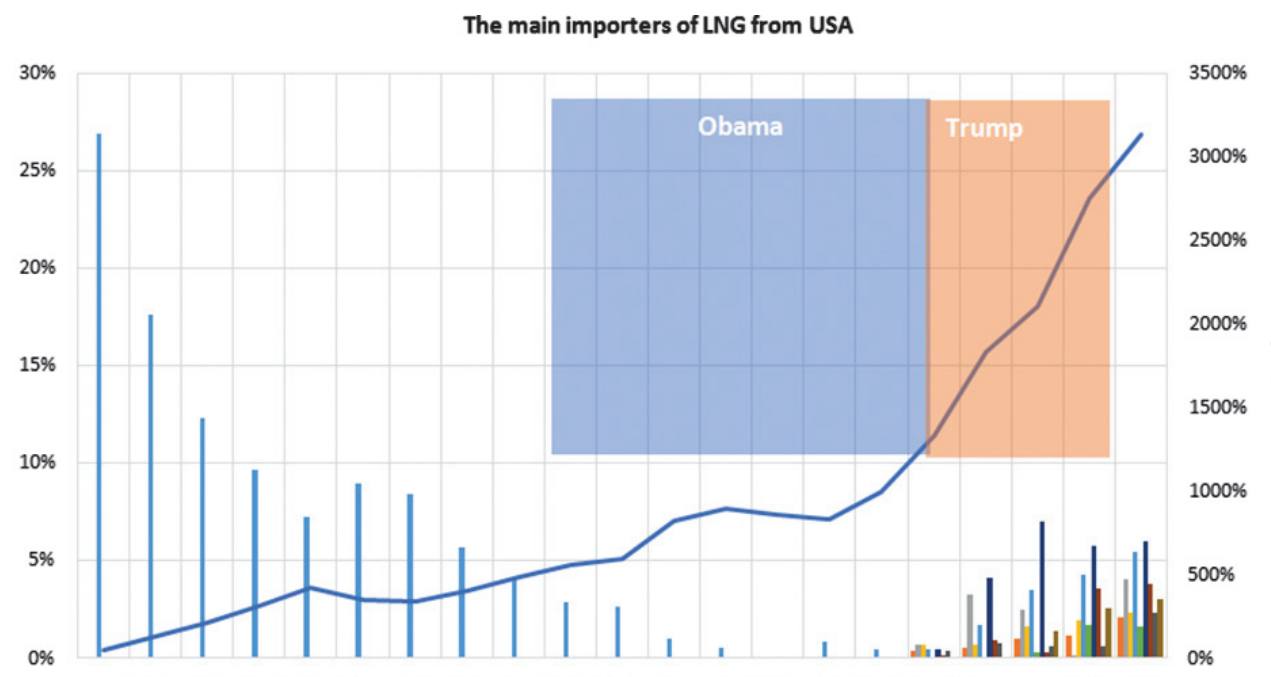

200020012002200320042005200620072008200920102011201220132014201520162017201820192020

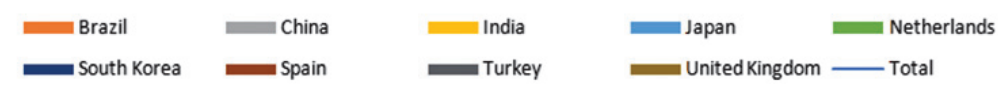

Fig.3: The main importers of LNG from USA to $40 \%$, and under Donald Trump reached $71 \%$. Oil production growth reached $40 \%$ under Barack Obama and 93\% under Donald Trump (EIA U. E., U.S. Field Production of Crude Oil (Thousand Barrels), 2021).

Gas imports to the United States tend to decline mainly due to a decrease in supplies from African countries, as well as Latin American countries. Canada and Mexico, which supply pipeline gas to the border regions of the United States, remained on the American market. Over the past 20 years, LNG exports from the United States have grown significantly, reaching an increase of $3132 \%$ compared to 1999 . The geography of deliveries has significantly expanded. If from 2000 to 2015 deliveries were carried out mainly to Japan, then, starting from 2016, deliveries began to affect not only the countries of South America and old Europe, but also to the new EU countries, including the Baltic States. Thus, the United States delivered 39,178 million $\mathrm{ft} 3$ of LNG to Lithuania from 2016 to 2020 (EIA U. E., U.S. Natural Gas Exports (MMcf), 2021). The geography and dynamic of US LNG export is shown in the Fig.3. provided in the Fig.2 (EIA U. E., Effects of removing restrictions on U.S. crude oil exports, 2015).

Gas production in the United States grew at the same rapid pace as oil, largely due to the growth of shale gas production, which in 2017 exceeded 400 billion cubic meters against 36 billion cubic meters in 2007 and 226 billion cubic meters in 2011 (EIA U. E., Annual Energy Outlook 2013., 2013). By 2040, gas production in the United States, according to experts of the International Energy Agency (IEA), can reach 1.06 trillion cubic meters. An $80 \%$ increase in gas production is expected to be provided by the production of shale gas (Ackerman, 2008). The growth of natural gas production over the past 20 years, compared to 1999, under Barack Obama was from 9\%
The "shale revolution" led not only to an increase in production, but also contributed to the growth of employment. As of 2013, about 2 million people were employed in energy-intensive industries, such as petrochemicals, fertilizers, synthetic resins, and plastics. According to analysts, this figure should grow to 3 million people by 2020 .

Starting in the 1970s, the United States began to move the most labor-intensive industries to other countries, which led to a reduction in the number of employed people in manufacturing industries from 20 million to 11 million in 2010. To solve the problem of employment in 2010, a specialized body was created - the President's Council on Jobs and 
Competitiveness, which included representatives of the government, large businessmen and employees of research institutes. By 2016, it was possible to increase the number of jobs to 12.3 million (Collins, 2016).

When Donald Trump came to power, he set a goal to increase the number of jobs to 25 million, primarily due to the return to the United States of industries that were previously withdrawn to other countries. The tax reform of D. Trump was supposed to be a factor contributing to the return of production in the United States. The goal of the reform was to create favorable conditions for business development as a result of reducing the tax burden on corporations from $35 \%$ to $21 \%$ (BLS, 2021). The dynamics of US employment in energy sector is shown in the Fig.4.

Despite the policy pursued by D. Trump to increase jobs, particularly in the energy sector, the main factor of employment in the energy sector was the "shale revolution", which provided peak values of jobs in the oil and gas industry under B. Obama. With the arrival of Donald Trump in the Oval office, employment in the US energy sector did not recover and continued to decline, reaching values in the oil and gas industry at the level of 2006. In the field of electricity generation from fuel combustion and renewable sources, including nuclear power, the values reached the lowest levels in the last 20 years. A similar situation has developed in the coal mining industry (BLS, 2021), which was a problem point in the strategy of "reindustrialization" launched under the presidency of D. Trump. Many American companies, mayors and state leaders opposed the decision of the US administration to withdraw from the Paris climate Agreement in June 2017 in favor of the development of the coal industry. France, Germany, Italy and other EU countries opposed the US withdrawal from the Paris Agreement.

As the main measures for the development of the coal industry, the Trump administration considered an increase in the share of coal in the total volume of energy exports, the implementation of effective infrastructure projects. The main
Employment in energy sector (thousands of persons)

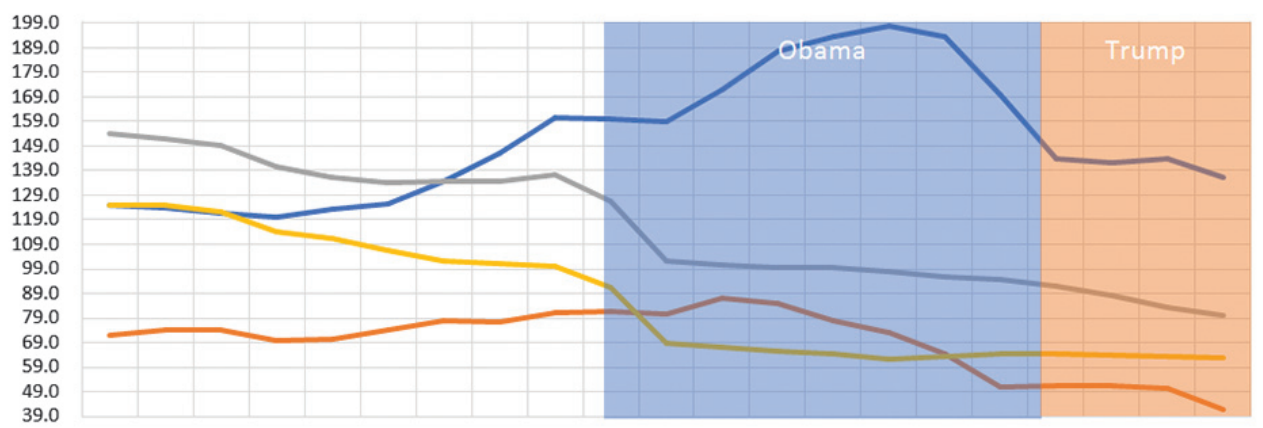

200020012002200320042005200620072008200920102011201220132014201520162017201820192020

Fig.4: Employment in energy sector

US coal data in short tons

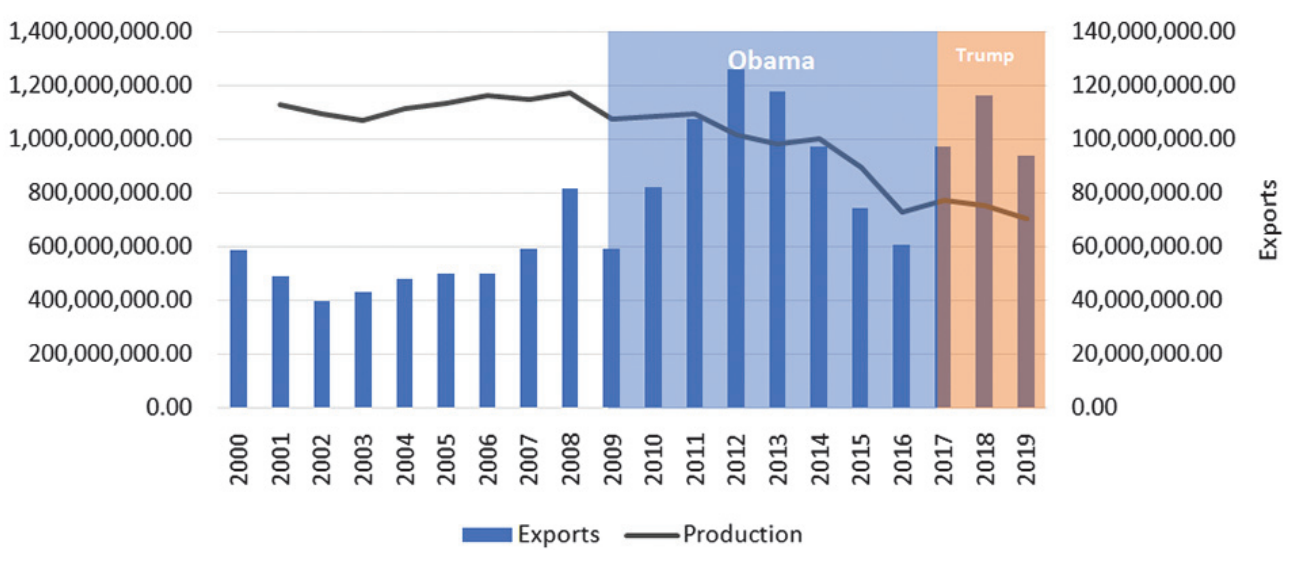

Fig.5: The US coal data

goal of D. Trump's energy strategy was to ensure the export of all types of energy resources to the largest possible number of consumers in all regions of the world. It was possible to increase the export of coal to the United States, first of all, due to the signing of an agreement in August 2017 by the American mining company Xcoal Energy with Ukraine on the supply of about 700 thousand tonnes of coal. The first delivery of coal was carried out in September 2017. At the same time, an agreement was reached to provide funds to Ukraine for the development of gas projects and wind energy.

In general, D. Trump failed to achieve a coal "renaissance". The automation of coal mining, the "shale revolution", and the accelerated development of alternative energy are holding back the development of the coal industry. At the same time, despite the decline in coal production, there was an increase in export supplies, which indicates the effectiveness of D. Trump's foreign energy strategy (EIA U. E., US coal data in short tonnes , 2021). The US coal data is provided in the Fig.5.

The oil industry has been more successful in the US energy sector. Thus, the lifting of the oil export embargo 
The main importers of Crude Oil and Petroleum Products from USA

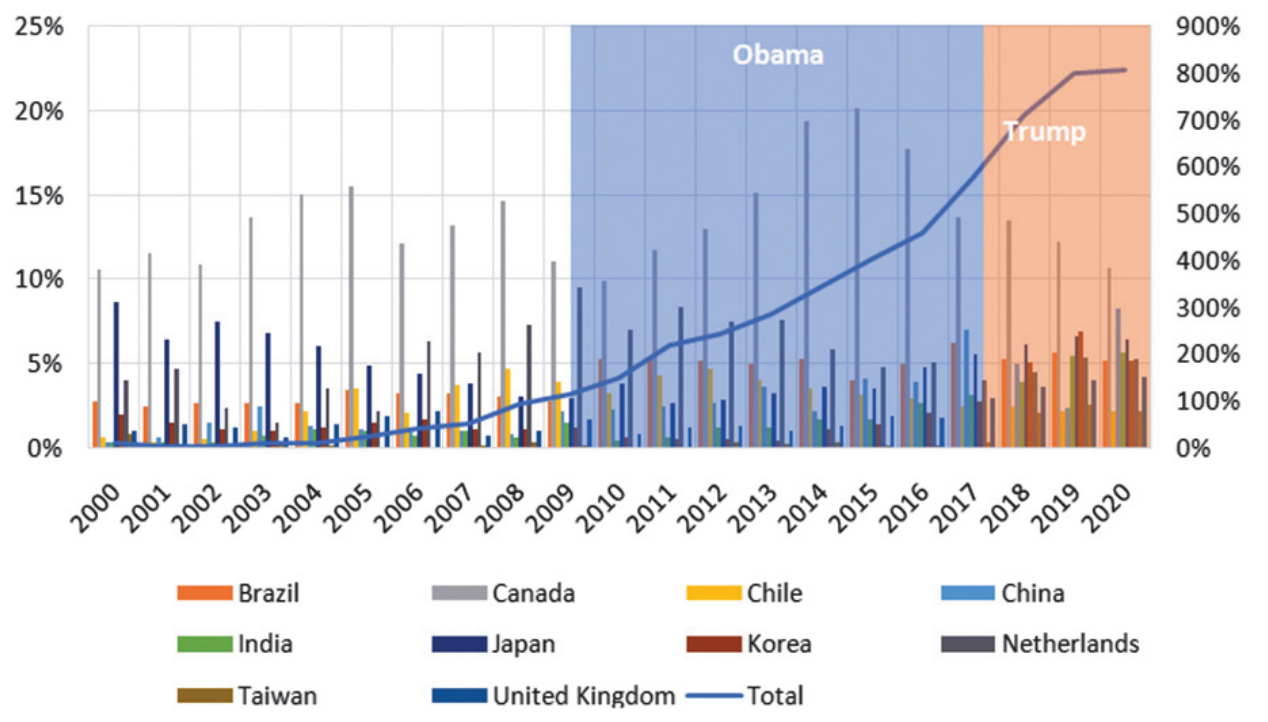

Fig.6: The main importers of crude oil and petroleum products from USA

Crude oil including lease condensate production (Mb/d)

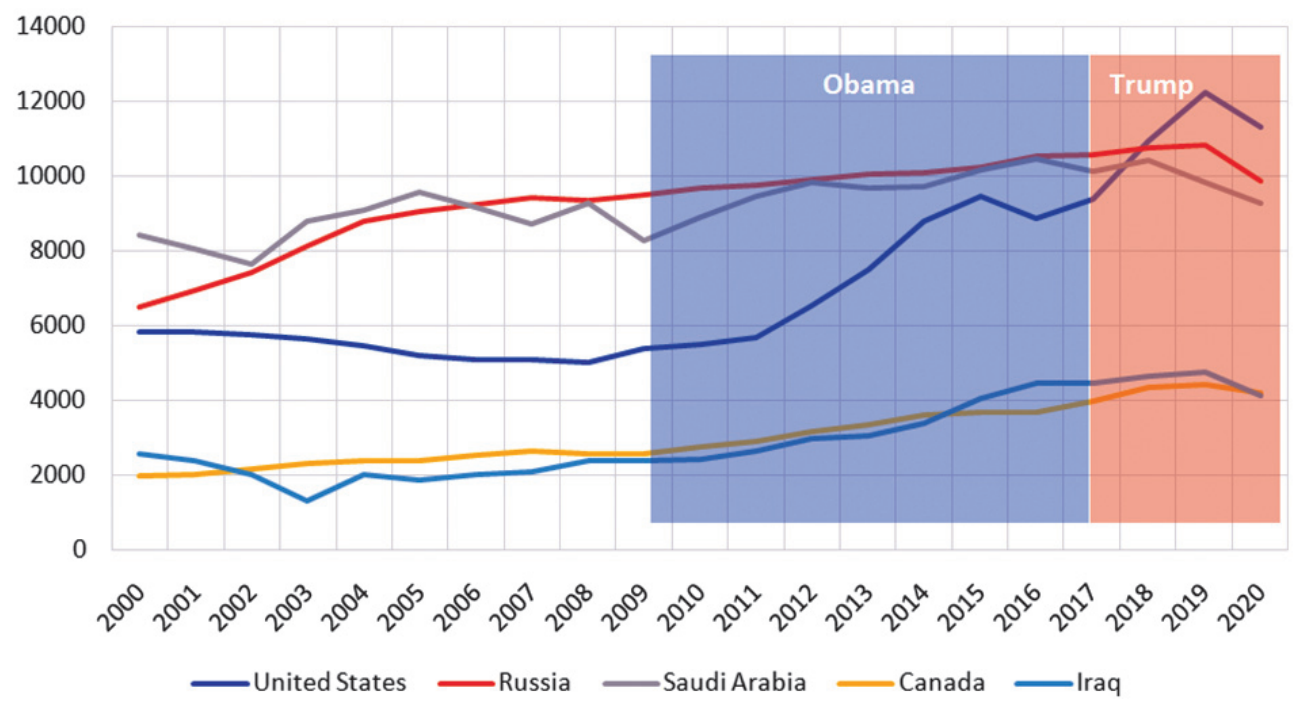

Fig.7: Crude oil including lease condensate production
American oil in recent years has become India, that replaced import of Iranian oil with American,which previously did not buy American energy raw materials. The growth of exports of oil and petroleum products from the United States compared to 1999 has increased 8-fold over the past 20 years, which is provided in the Fig.6 (EIA U. E., Total Crude Oil and Products Exports by Destination, 2021).

As part of the fulfilment of election promises, the Trump administration immediately announced the start of a plan to sharply increase oil and gas production on the American shelf by selling off oil fields. On March 21, 2018, an auction was held to lease thousands of land plots in the coastal area of the Gulf of Mexico. Zones on the shelf of the states of Texas, Louisiana, Mississippi, Alabama, and Florida were put up for auction (Finanz.ru, 2018). The temporary moratorium on deep-sea offshore drilling in coastal waters and issuance of exploration licences, which was in effect since 2010 due to the accident at the Deepwater Horizon oil platform in the Gulf of Mexico causing the largest oil release in US history, was cancelled.

As of 2018, the United increased the supply of American oil abroad. According to the Energy Information Administration of the US Department of Energy, oil exports in March 2018 averaged 1.5 million barrels per day, which is almost 1.5 times higher than in 2017. The export growth factors were: increased oil production and infrastructure development. Oil imports in March 2018 amounted to 7.5 million barrels per day (TADVISER, 2020).

The list of countries importing American oil has increased from 27 to 37. Canada ranks first in terms of imports of American oil. Canada receives one-third of American oil exports, and China receives one-fifth of oil exports. The United Kingdom closes the top three, which imports a tenth of the oil exported by the United States. The importer of
States has overtaken Saudi Arabia in terms of oil and gas exports, taking a leading position in the global oil market. In 2019-2020, the United States retained the first place in the world in oil production (EIA U. E., Crude oil including lease condensate production, 2021), which is shown in the Fig.7.

The main oil suppliers in the United States since 2014 are Mexico and Canada, surpassing the traditional oil suppliers from the Persian Gulf countries, which forced a number of countries to look for other markets besides Iran, from which oil is not supplied to the United States in modern history (EIA U. E., U.S. Crude Oil Imports., 2021). However, the current actions of the administration of J. Biden's efforts to move the US energy complex towards green energy are changing the 
current geography of supply. So, immediately after the inauguration, President J. Biden signed a decree to stop the construction of the Keystone XL oil pipeline, through which oil from Canada, with a capacity of 830 thousand barrels per day, was to be pumped to refineries in the southern United States (Alifirova, 2021). By rejecting the "legacy" of Trump, the new head of the United States hits the economic interests of an ally. The province of Alberta, for example, immediately loses $\$ 1.1$ billion, which it invested in the project in 2020. In this situation, the suppliers of Russian oil, which began to pass part of the American refineries after the embargo on the import of raw materials from Venezuela, can win.

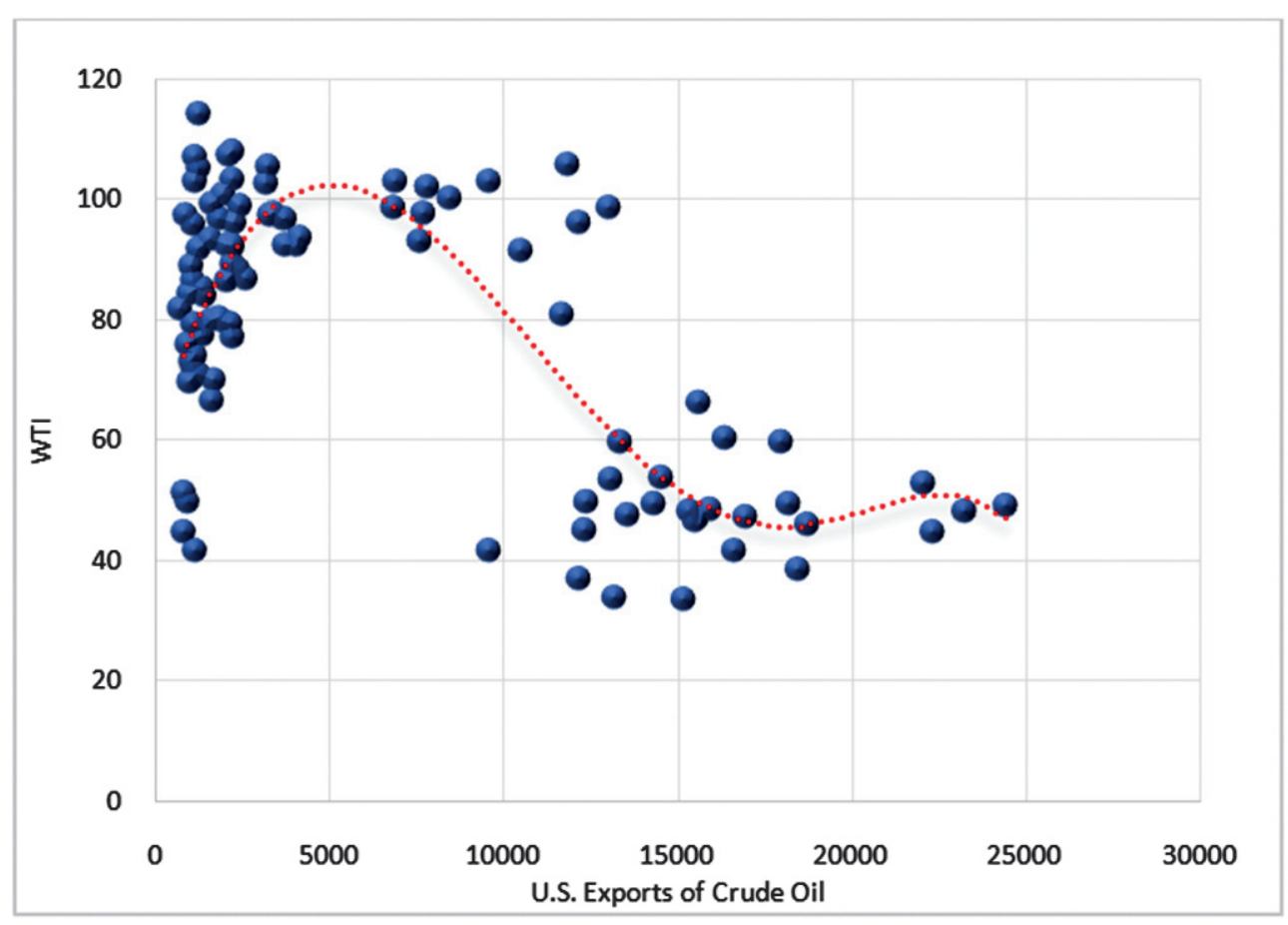

Fig.8: Dependence of WTI prices on US export of crude oil

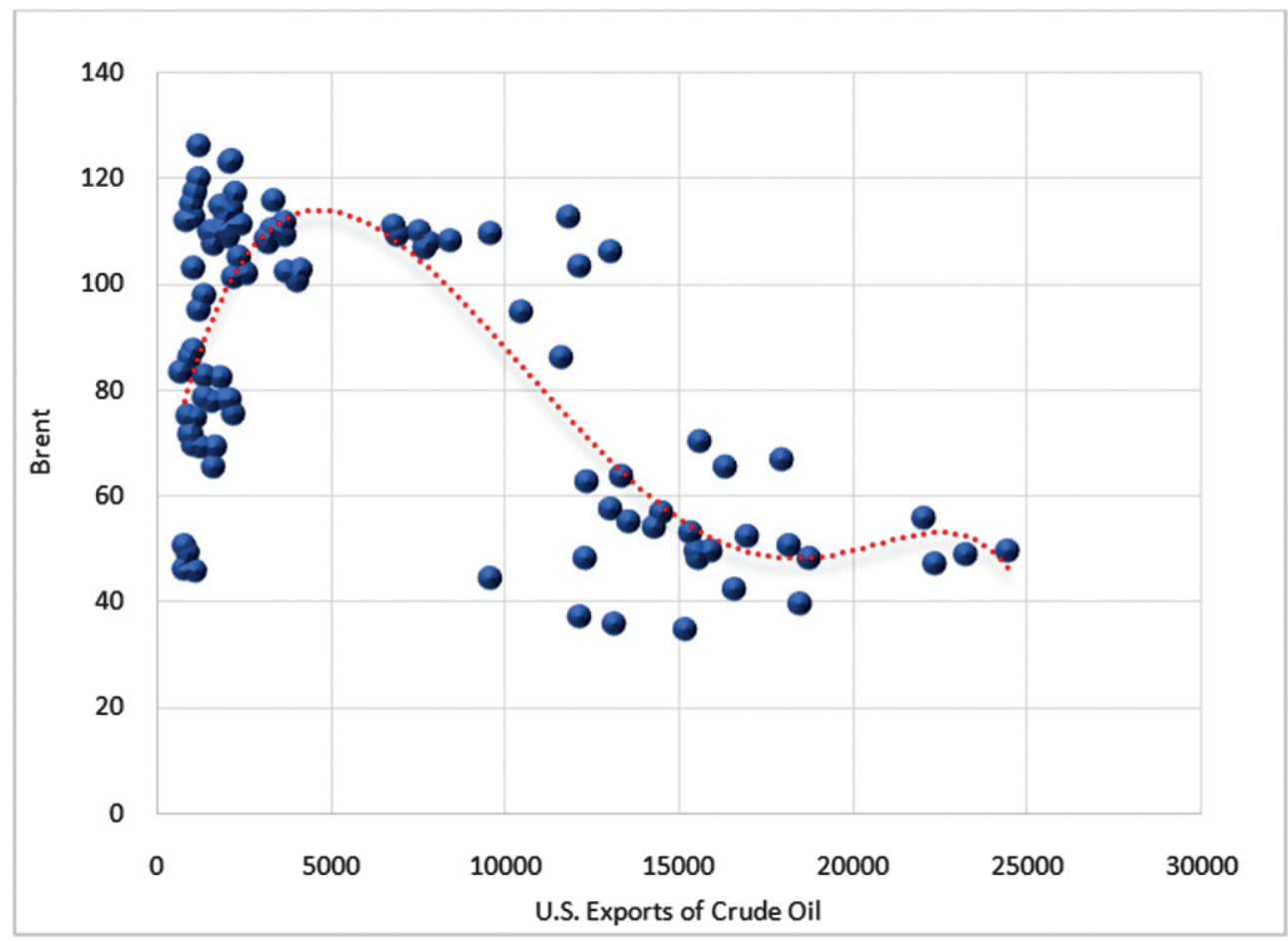

Fig.9: Dependence of Brent prices on US export of crude oil
The growth of production and exports in the US oil and gas industry has had an impact on the dynamics of world oil prices. To determine the degree of interaction and the nature of this influence, we have constructed two curved regression equations, where the dependent variables are the prices of crude oil: WTI and Brent. The following variables are taken as independent variables: Field production of crude oil, exports of crude oil, natural gas gross withdrawals, natural gas exports. To assess the influence of independent variables on dependent ones during the actions of the Obama and Trump administrations, two periods were introduced. First: January 2009 - January 2017 Second period: February 2017 December 2020.

To assess the nature of the dependence, a correlation was calculated with a significance of $0.5<\mathrm{R}>0.5$. The results showed that the effective interaction between the variables was carried out during the presidency of Barack Obama, when exports of crude oil affected the price dynamics of oil quotes with an inverse relationship. The correlation matrix is provided in the Table 1.

Graphically, the dependence of WIT and Brent prices on the US export of crude oil can be observed in the two following graphs (Figs. 8 and 9), provided for each of the dependent variables. 
TABle 1: Correlation MATRIX

\begin{tabular}{|c|c|c|c|c|}
\hline \multirow{3}{*}{$\begin{array}{l}\text { Dates } \\
\text { Variables }\end{array}$} & \multicolumn{4}{|c|}{ Correlation matrix } \\
\hline & \multicolumn{2}{|c|}{$2009-2017$} & \multicolumn{2}{|c|}{$2017-2020$} \\
\hline & W T I & Brent & WTI & Brent \\
\hline $\begin{array}{l}\text { U.S. field production of } \\
\text { crude oil (Thousand barrels) }\end{array}$ & $-0,414$ & $-0,377$ & $-0,028$ & 0,076 \\
\hline $\begin{array}{l}\text { U.S. exports of crude oil } \\
\text { (Thousand barrels) }\end{array}$ & $-0,615$ & $-0,592$ & $-0,297$ & $-0,234$ \\
\hline $\begin{array}{l}\text { U.S. natural gas gross } \\
\text { withdrawals (MMcf) }\end{array}$ & $-0,363$ & $-0,301$ & $-0,210$ & $-0,130$ \\
\hline $\begin{array}{l}\text { U.S. natural gas exports } \\
\text { (MMcf) }\end{array}$ & $-0,374$ & $-0,301$ & $-0,423$ & $-0,386$ \\
\hline
\end{tabular}

The obtained dependence graphs can be interpreted in the following equations with the obtained determination coefficients, where the variable $x$ is an independent variable:

$$
\begin{aligned}
& \begin{aligned}
W T I & =-4 E-24 x^{6}+2 E-19 x^{5}-3 E-15 x^{4}+1 \mathrm{E}-10 x^{3}-3 E-06 x^{2} \\
& +0,0184 x+61,922
\end{aligned} \\
& \begin{aligned}
\mathrm{R}^{2}= & 0,5751 \\
\text { Brent } & =-1 \mathrm{E}-23 x^{6}+9 \mathrm{E}-19 x^{5}-3 E-14 x^{4}+5 E-10 x^{3}-6 E-06 x^{2} \\
& +0,0303 x+58,488
\end{aligned} \\
& \mathrm{R}^{2}=0,5498
\end{aligned}
$$

\subsection{Conclusion}

The current US energy policy under the last three presidents is a clear example of opposing approaches to addressing energy security issues in the face of technological changes in the oil and gas industry and the COVID-19 pandemic. The strategy of Barack Obama, which is being implemented, is being continued by the current President, J. Biden, in the first place, puts the development of renewable energy sources, which have not been widely developed due to the "shale boom" and the uncompetitiveness of "green energy" against this background.

Today, the situation is quite different, due to the spread of COVID-19, the high cost of production in the oil and gas industry, and the fall in world prices for hydrocarbons, the development of "green energy" seems more realistic under the administration of J. R. R. Tolkien. Biden, which negates D. Trump's efforts to develop traditional energy to strengthen the economic potential of the United States.

\section{References}

1. Ackerman, S. (2008): The Obama Doctrine. The American Prospect. Retrieved from https:// prospect.org/features/obama-doctrine/

2. Alifirova, Е. (2021): Д. Байден вступил в должность президента США. Ждем «революцию чистой энергии». Neftegaz.ru. Retrieved from https:/neftegaz.ru/news/ politics/660222-d-bayden-vstupil-v-dolzhnostprezidenta-ssha-zhdem-revolyutsiyu-chistoy-energii/
3. ARPA-E. (2014): ARPA-E's FY15 budget request. Retrieved from https://www.arpa-e.energy.gov/pdfs/ fiscal-year-2015-budget-request

4. BLS, U. B. (2021): Employment in energy sector . Retrieved from https://data.bls.gov/cgi-bin/dsrv?ce

5. Clayton, B. (2013): The Case for Allowing U.S. Crude Oil Exports. Retrieved from https://www.cfr.org/report/ case-allowing-us-crude-oil-exports

6. Collins, M. (2016): How to Create Manufacturing Jobs. IndustryWeek. Retrieved from https:// ww w. industryweek. com/the-econom y/ competitiveness/article/22007282/how-to-createmanufacturing-jobs

7. EIA, U. E. (2013): Annual Energy Outlook 2013. Retrieved from https:/www.eia.gov/todayinenergy/ detail.php?id=10831

8. EIA, U. E. (2015): Effects of removing restrictions on U.S. crude oil exports . Retrieved from https:// Www.eia.gov/analysis/requests/crude-exports/

9. EIA, U. E. (2021): Carbon dioxide emissions from energy consumption. Retrieved from https:// www.eia.gov/ totalenergy/data/browser/ xls.php?tbl= $\mathrm{T} 11.01 \&$ freq $=\mathrm{m}$

10. EIA, U. E. (2021): Crude oil including lease condensate production. Retrieved from https: //www.eia.gov/ international/data/world/ petroleum-and-other-liquids/ annual-petroleum-and-other-liquids-production? $\mathrm{pd}=5 \& \mathrm{p}=00000000000000000000000000000000002 \& \mathrm{u}$ $=0 \& \mathrm{f}=\mathrm{A} \& \mathrm{v}=$ mapbubble\&a $=-\& \mathrm{i}=$ none\&vo $=$ value \&t $=\mathrm{C} \& \mathrm{~g}=000000000000000000000000$ 00000000000000000000000

11. EIA, U. E. (2021): Total Crude Oil and Products Exports by Destination . Retrieved from https://www.eia.gov/ dnav/pet/pet_move_expc_a_ep00_eex_mbbl_a.htm

12. EIA, U. E. (2021): U.S. Crude Oil Imports. Retrieved from https://www.eia.gov/dnav/pet/pet_move_impcus _a2_nus_epc0_im0_mbbl_m.htm

13. EIA, U. E. (2021): U.S. Field Production of Crude Oil (Thousand Barrels). Retrieved from https: // www.eia.gov/dnav/ pet/hist/LeafHandler.ashx?n = PET\&s $=$ MCRFPUS1\&f $=\mathrm{A}$

14. EIA, U. E. (2021): U.S. Natural Gas Exports (MMcf). Retrieved from https://www.eia.gov/dnav/ng/hist/ n9130us2a.htm

15. EIA, U. E. (2021): US coal data in short tonnes. Retrieved from https: //www.eia.gov/coal/ data/ browser/ \#/topic/41 ?agg = 2,1,0\&rank = ok\&linechart $=$ COAL. EXPORT_QTY.TOT-TOT-TOT.A \& columnchart $=$ COAL.EXPORT_QTY.TOT-TOT- 
TOT.A\&map $=$ COAL.EXPORT_QTY.TOT-TOTTOT. A\&freq $=$ A\&start $=2000 \&$ end $=2019 \&$ ctype $=$ map\&ltype $=$ pin\&rtype $=$ s\&maptype $=0 \&$ rse $=0 \& p$

16. Finanz.ru. (2018): США объявили рекордную в истории распродажу нефтегазового шельфа. Finanz.ru. Retrieved from https: //www.finanz.ru/novosti/ birzhevyye-tovary/ ssha-obyavili-rekordnuyu -vistorii- rasprodazhu-neftegazovogo- shelfa1017281009

17. Koranyi., D. (2016): A US Strategy for Sustainable Energy Security. The Atlantic Council of the United States. Retrieved from https: //espas.secure.europarl. europa.eu/orbis/ sites/default/files/ generated/ document/ en/AC_SP_Energy.pdf

18. Larsen, J., Mohan, S., Marsters, P., and Herndon., W. (2018): Energy and environmental implications of a carbon tax in the United States. Columbia Sipa Center On Global Energy Policy. Retrieved from https: // energypolicy.columbia.edu/ sites/default/ files/ pictures/CGEP_Energy_Environmental_Impacts CarbonTax_FINAL.pdf
19. Letter, A. O. (2008): Securing America's Energy Future: An open letter to the 44th President of the United States and the 111th U.S. Congress. Retrieved from https: //www.globalenergyinstitute.org/ securingamericas-energy- future-open-letter-44th -presidentunited- states-and- 111th-congress

20. Lu, Y., Khan, Z., Alvarez-Alvarado, M., Zhang, Y., Huang, Z., and Imran, M. (2020): A Critical Review of Sustainable Energy Policies for the Promotion of Renewable Energy Sources. Sustainability (12, No.12: 5078). doi:https: //doi.org/10.3390/su12125078

21. Poneman, D. (2017): American Energy Policy. Harvard Kennedy School. Retrieved from https: // www.belfercenter.org/ sites/default/files/ files/ publication/ Poneman \%20American \%20Energy \%20Policy_0.pdf

22. Schacht, W. H. (2009): Technology Transfer: Use of Federally Funded Research and Development. Congressional Research Service. Retrieved from https: //www.everycrsreport.com/ files/20091105_RL33527 ff620510d24019efb0c905b1e29365aa04baaec9.pdf

\section{STATEMENT OF OWNERSHIP AND OTHER PARTICULARS ABOUT JOURNAL OF MINES, METALS \& FUELS \\ REGISTRATION OF NEWSPAPERS (CENTRAL RULES, 1956 (AS AMENDED) \\ FORM IV (Rule 8)}

1. Place of publication

2. Periodicity of its publication

3. Printer's Name

Whether citizen of India?

Address

4. Publisher's Name

Whether citizen of India ?

Address

5. Hony. Chief Editor

Whether citizen of India?

Address

6. Managing Editor

Whether citizen of India ?

Address

7. Names and addresses of individuals who own the newspaper and partners and shareholders holding more than one per cent of the total capital.

I, Pradip Kumar Chanda hereby declare that the particulars given above are true to the best of my knowledge and belief.
$\mathrm{Sd} /$

Pradip Kumar Chanda

... 62 Lenin Sarani, Kolkata 700013

... Pradip Kumar Chanda

... Indian Citizen

... 62 Lenin Sarani, Kolkata 700013

... Pradip Kumar Chanda

... Indian Citizen

... 62 Lenin Sarani, Kolkata 700013

... Jayanta Bhattacharya

... 62 Lenin Sarani, Kolkata 700013

... Pradip Kumar Chanda

... Indian Citizen

.. 9A Sarat Chatterjee Road, P.O. Nabagram 712246, Hooghly

BOOKS \& JOURNALS PRIVATE LTD.

(nolders

Pradip Kumar Chanda, 9A Sarat Chatterjee Road, P.O. Nabagram 712246, Hooghly, Mrs. B. Chanda, 9A Sarat Chatterjee Road, P.O. Nabagram 712246, Hooghly.

\section{Publisher}

... Monthly

... Indian Citizen

Date : 28th April 2021 